\title{
Three skin cancers in one: an extremely rare collision tumour
}

\author{
Anna Rose 다, ' Suzanne E Thomson, ${ }^{2}$ Lucy Melly, ${ }^{3}$ Nikolaos Arkoulis ${ }^{4}$
}

${ }^{1}$ Orthopaedics, NHS Ayrshire and Arran, Ayr, UK

${ }^{2}$ Canniesburn Plastic Surgery and Burns Unit, Glasgow Royal Infirmary, Glasgow, UK ${ }^{3}$ Histopathology, Queen Elizabeth University Hospital, Glasgow, UK

${ }^{4}$ Plastic Surgery, Glasgow Royal Infirmary, Glasgow, UK

\section{Correspondence to}

Anna Rose:

annafreyarose@gmail.com

Accepted 8 June 2021

\section{DESCRIPTION}

Melanoma and non-melanoma skin cancers, namely squamous cell carcinomas (SCCs) and basal cell carcinomas (BCCs), are becoming increasingly prevalent ${ }^{12}$ and demand an increasing share of resources. ${ }^{3}$ Collision tumours are classified as two independent neoplasms that occur at the same anatomical site in close proximity to one another, yet maintain distinct boundaries. ${ }^{4}$ While there are several reported cases of collision tumours containing melanomas and either BCCs or SCCs, the development of BCC, SCC and melanoma at a single site is extremely rare and has only been described once in the English literature before. ${ }^{5}$ Here we present a malignant cutaneous collision tumour containing all three components. An 82-year-old man, with a history of multiple nonmelanoma skin cancers, presented with a 3-month history of a rapidly growing and tender $4 \mathrm{~cm}$ raised keratotic ulcerated lesion on the upper pole of his right pinna comprising two contiguous nodules, as shown in figure 1 . His medical history was unremarkable except for hypertension. On examination, there were no other skin lesions of concern and no palpable lymphadenopathy. The appearances of the lesion were fairly typical of an SCC and the lesion was excised under local anaesthetic as a wedge of

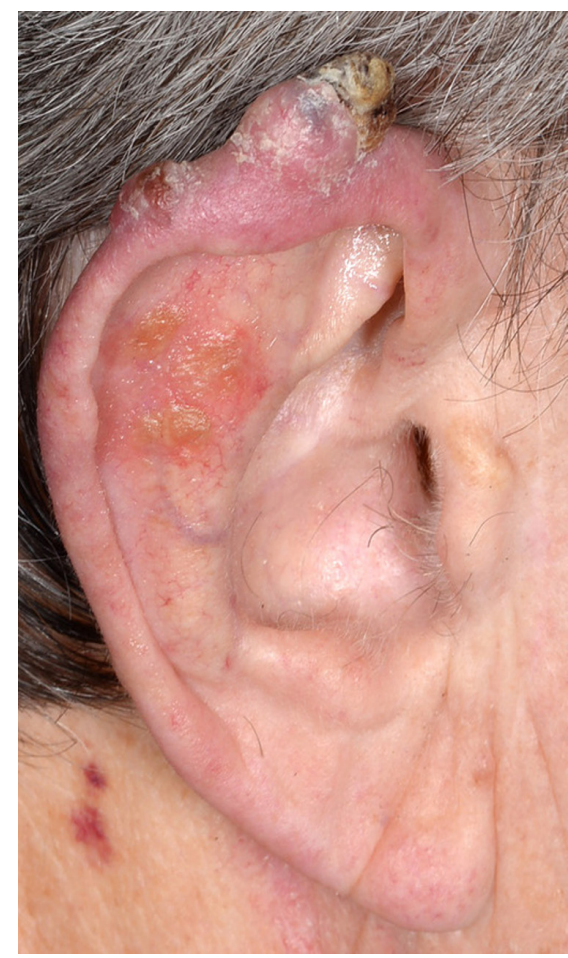

Figure 1 Photo of the lesion at presentation.

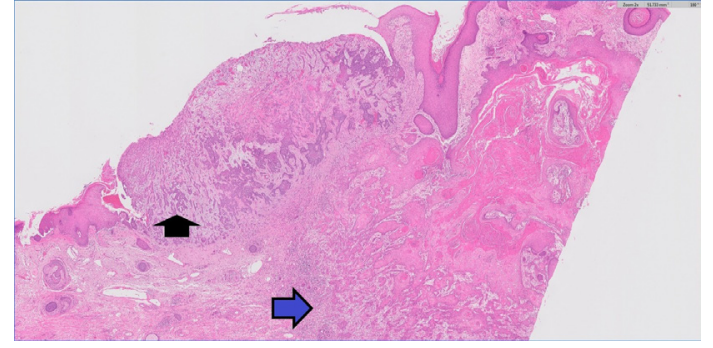

Figure 2 The photo shows infiltrative basal cell carcinoma (black arrow) with moderately differentiated squamous cell carcinoma immediately adjacent (blue arrow). Though they are immediately adjacent to each other, they are separate tumours with no transition between the two tumours and originating from separate points of the epidermis, therefore they are considered to be a collision of basal cell carcinoma and squamous cell carcinoma rather than basosquamous carcinoma. This is at magnification $\times 2$.

skin and cartilage with $6 \mathrm{~mm}$ margins as per UK guidelines for a high-risk tumour. ${ }^{2}$ Recovery was uneventful. Macroscopic description of the lesion was a pale keratotic nodule measuring $31 \times 9 \times 8$ $\mathrm{mm}, 5 \mathrm{~mm}$ from the medial and lateral margins of the specimen. The BCC was immediately lateral to the SCC and the melanoma was medial to the SCC (separated from the SCC by approximately $7 \mathrm{~mm}$ of normal skin). Microscopy of the excision biopsy revealed three tumours within the specimen: (1) a moderately differentiated SCC (pT2); (2) an infiltrative basal cell carcinoma (pT1) (figure 2) and (3) an invasive pT3a nodular melanoma, $2.8 \mathrm{~mm}$ Breslow (figures 3 and 4). Excision margins were clear for all lesions and staging CT did not show any distant metastatic disease. The patient was referred to the skin multidisciplinary team (MDT) for further management. Following MDT recommendations, he was treated with $1 \mathrm{~cm}$ wide local

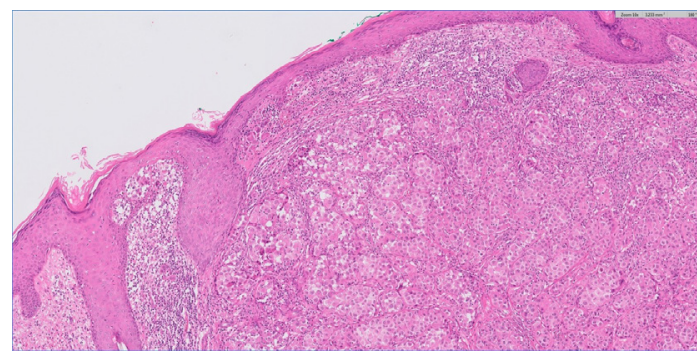

Figure 3 The photo shows invasive melanoma which is from a different section of the same specimen with $\mathrm{H} \& \mathrm{E}$ staining, this is at magnification $\times 10$. 




Figure 4 The photo shows the invasive melanoma with Melan-A staining, this is at magnification $\times 5$.

excision of the scar to comply with current melanoma guidelines; ${ }^{6}$ histology of the wide excision did not show any residual malignancy. Despite the value of sentinel lymph node biopsy in the prognosis, staging and access to systemic treatments in melanoma, ${ }^{7}$ this was deemed not to be in the best interests of this patient due to his age and the fact that this occurred at the peak of the COVID-19 pandemic. He is currently under long-term follow-up.

Following a review of the literature, we identified only one other similar case of a triple collision tumour, reported by

\section{Patient's perspective}

I am grateful for the efficient and speedy way that I was treated. My thanks to all concerned with my care.

\section{Learning points}

Even typical-looking skin malignancies can be combined tumours containing more than one type of skin cancer.

- Collision tumours must be treated with guidance from a tertiary skin multidisciplinary team and each tumour component should be treated according to current guidelines in terms of excision margins, staging modalities and adjuvant treatments.
Cornejo and Deng ${ }^{5}$ in 2013. This was a male patient of similar age (84 years) who developed a combined and collision basosquamous melanocytic malignant tumour on the anterior chest. Since two of the three tumours described featured intimate admixing of the tumour cell populations, the authors described this as both a combined and collision tumour and it was treated with wide local excision. The patient was followed up for 6 months and showed no evidence of recurrence. Our case differs in that cell populations for all three tumours were separate, which likely makes this the only reported case of a true, three-tumour collision malignancy.

\section{Twitter Anna Rose @a_f_rose}

Contributors AR researched the topic and wrote the article. SET contributed to the first draft and final edits. LM provided the histology photographs and pathological description. NA conceptualised the idea and contributed to final edits. All authors participated in patient care and approved the final version of the article.

Funding The authors have not declared a specific grant for this research from any funding agency in the public, commercial or not-for-profit sectors.

Competing interests None declared.

Patient consent for publication Obtained.

Provenance and peer review Not commissioned; externally peer reviewed.

\section{ORCID iD}

Anna Rose http://orcid.org/0000-0001-6346-2796

\section{REFERENCES}

1 Non-Melanoma skin cancer statistics. Available: https://www.cancerresearchuk.org/ health professional/cancer-statistics/statistics-by-cancer-type/non-melanoma-skincancer\#heading-One [Accessed Sep 2020].

2 National Institute for Health and Care Excellence. Improving outcomes for people with skin tumours including melanoma. NICE, 2010.

3 Vallejo-Torres L, Morris S, Kinge JM, et al. Measuring current and future cost of skin cancer in England. J Public Health 2014;36:140-8.

4 Satter EK, Metcalf J, Lountzis N, et al. Tumors composed of malignant epithelial and melanocytic populations: a case series and review of the literature. J Cutan Pathol 2009;36:211-9.

5 Cornejo KM, Deng AC. Malignant melanoma within squamous cell carcinoma and basal cell carcinoma: is it a combined or collision tumor?--a case report and review of the literature. Am J Dermatopathol 2013;35:226-34.

6 National Institute for Health and Care Excellence. Melanoma: assessment and management. NICE, 2015.

7 Peach $\mathrm{H}$, Board R, Cook M, et al. Current role of sentinel lymph node biopsy in the management of cutaneous melanoma: a UK consensus statement. J Plast Reconstr Aesthet Surg 2020;73:36-42.

Copyright 2021 BMJ Publishing Group. All rights reserved. For permission to reuse any of this content visit https://www.bmj.com/company/products-services/rights-and-licensing/permissions/

BMJ Case Report Fellows may re-use this article for personal use and teaching without any further permission.

Become a Fellow of BMJ Case Reports today and you can:

- Submit as many cases as you like

Enjoy fast sympathetic peer review and rapid publication of accepted articles

- Access all the published articles

Re-use any of the published material for personal use and teaching without further permission

Customer Service

If you have any further queries about your subscription, please contact our customer services team on +44 (0) 2071111105 or via email at support@bmj.com.

Visit casereports.bmj.com for more articles like this and to become a Fellow 